\title{
Removal of Contaminants and Pathogens from Secondary Wastewater Effluents using Hollow Fiber Microfiltration Membranes
}

\author{
Mahmoud Bali* and Soumaya Farhat \\ Higher Institute of Sciences and Techniques of Water, University of Gabès, Tunisia
}

Submission: January 10, 2020; Published: January 24, 2020

*Corresponding author: Mahmoud Bali, Higher Institute of Sciences and Techniques of Water, University of Gabès, Tunisia

\begin{abstract}
The main purpose of this study was to investigate the ability of cross-flow microfiltration technique to treat urban wastewater effluents. Experimental results demonstrated that this technique is reliable and very effective in removing wastewater impurities. Results showed that hollow fiber membranes achieved a significant removal rate of all parameters tested except ammonium nitrogen. This study confirmed that cross-flow microfiltration process is very efficient concerning the abatement of suspended solids and organic matter. All pathogenic bacteria indicators were removed by this process. The experimental study demonstrated that quality of permeate produced by hollow fiber microfiltration membranes is suitable for industrial reuse.
\end{abstract}

Keywords: Treatment; Hollow fiber; Secondary effluent; Cross-flow microfiltration

\section{Introduction}

During the last few years there has been a continuous and important growth in water consumption and consequently a strong increase of the domestic and industrial wastewater potential sources of environmental problems. Reclamation of wastewater in thus becoming a major goal in several countries where there is water scarcity [1]. Conventional water and wastewater treatment processes have been long established in removing many chemical and microbial contaminants of concern to public health and the environment. However, the effectiveness of these processes has become limited over the last two decades [2].

Developmentofnew technologieshasextended thepossibilities of wastewater reuse [3]. At the same time, norms regarding the quality of water to be reused have become increasingly stringent, while tertiary treatments have in turn become increasingly sophisticated as they strive to obtain effluents of high quality [4]. Advanced treatment technologies have been demonstrated to remove various potentially harmful compounds that could not be effectively removed by conventional treatment process [2]. Membrane based separation processes have gradually become an attractive alternative to the conventional separation processes in the treatment of wastewater. The advantages of membrane technology over conventional separation methods are high removal capacity, flexibility of operation and cost effectiveness. However, the main limitation to the greater use of membrane technology is membrane fouling [5]. The application of membrane filtration processes not only enables high removal efficiencies, but also allows reuse of water and some of the valuable waste constituents [6]. Membrane technologies obtain effluents which meet the standards established in wastewater reuse [7] and are extensively employed as wastewater tertiary treatments [4]. Membrane technologies provide an important solution in environmental fields such as pollution reduction and water reuse [8-10]. Membrane filtration is one of the most promising technologies used for the advanced treatment of secondary effluents [11]. Among membrane processes, microfiltration (MF) is a widely used technique in treating contaminated water and wastewater [12]. MF is operated in the cross-flow as well as the dead-end mode. In cross-flow microfiltration (CFMF), the suspension is pumped tangentially over the membrane surface. Clear liquid permeates the filtration medium and is recovered as the permeate, while the solids accumulate at the filtration barrier to form a fouling layer, or cake. The tangential suspension flow tends to limit the growth of the cake. For this reason, CFMF is preferably applied for the filtration of liquids having high solids content. In dead-end filtration, the suspension flows perpendicular to the membrane surface so that the retained particles accumulate at the membrane surface and form a cake which decreases the permeate flux.

Cross-flow microfiltration is an efficient and energy-saving process that has been widely used in separating fine particles 
[13]. A membrane filtration unit can be placed at the very end of the wastewater treatment line, treating wastewater from various sources after traditional pretreatment and biological degradation [14]. It is expected that the use of membrane filtration for treatment of municipal wastewater will steadily increase with more stringent discharge regulations and fresh water supply limitations. In response, ultrafiltration and microfiltration membrane suppliers have developed a number of different membrane structures and operating procedures for wastewater treatment [15]. Hollowfiber membranes have been widely employed for water and wastewater treatment [16]. However, the major obstacle is the flux decline due to the membrane fouling [17], which remains one of the most problematic issues surrounding membrane use in water and wastewater treatment applications [18].

The main objective of this study is to evaluate the applicability of cross-flow microfiltration technique in treating secondary effluent of urban wastewater for industrial reuse.

\section{Materials and Methods}

\section{Wastewater origin}

We carried out filtration trials using secondary wastewater effluents produced by the treatment plant of the town of Gabès (south-east of Tunisia) which uses activated sludge treatment. The capacity of this plant is about $17.000 \mathrm{~m}^{3}$ per day. The average characteristics of the secondary wastewater effluent are given in Table 1.

Table 1: Average characteristics of the secondary wastewater effluent.

\begin{tabular}{|c|c|}
\hline Parameter & Value \\
\hline $\mathrm{pH}$ & 6.97 \\
\hline Temperature $\left({ }^{\circ} \mathrm{C}\right)$ & 20.5 \\
\hline Electric conductivity $(\mathrm{mS} / \mathrm{Cm})$ & 3.32 \\
\hline Turbidity $(\mathrm{NTU})$ & 178.22 \\
\hline $\mathrm{SS}(\mathrm{mg} / \mathrm{L})$ & 100.55 \\
\hline $\mathrm{COD}(\mathrm{mg} / \mathrm{L})$ & 383.94 \\
\hline $\mathrm{BOD}_{5}(\mathrm{mg} / \mathrm{L})$ & 261.45 \\
\hline $\mathrm{NH}_{4 .} \mathrm{N}(\mathrm{mg} / \mathrm{L})$ & 173.15 \\
\hline $\mathrm{TC}(\log \mathrm{UFC} / 100 \mathrm{~mL})$ & 5.62 \\
\hline $\mathrm{FC}(\log \mathrm{UFC} / 100 \mathrm{~mL})$ & 2.78 \\
\hline $\mathrm{FS}(\log \mathrm{UFC} / 100 \mathrm{~mL})$ & 0.92 \\
\hline
\end{tabular}

\section{Experimental set-up}

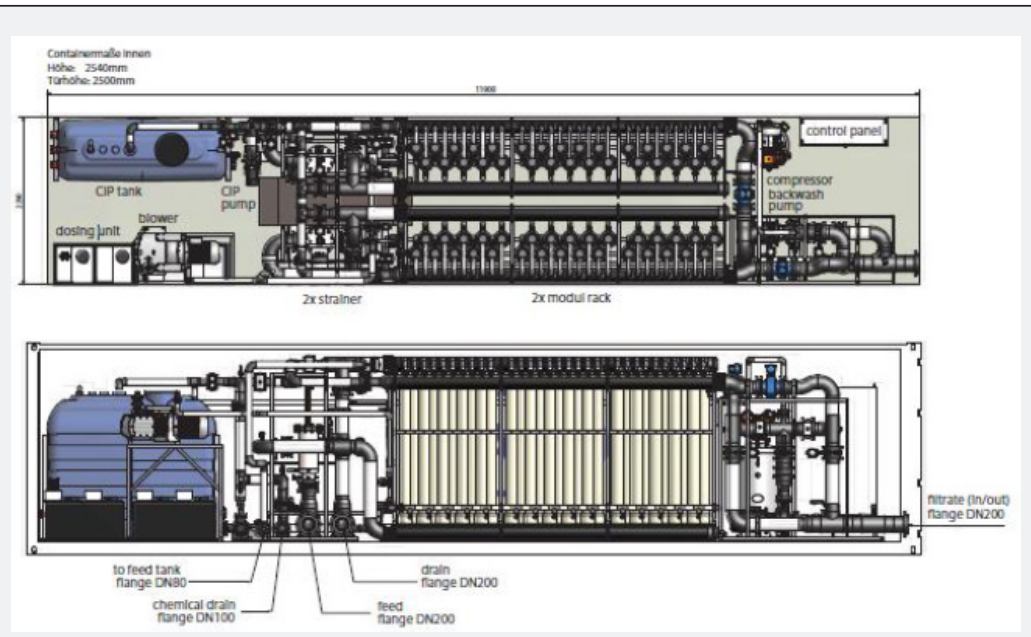

Figure 1: Diagram of Pall AriaTM Mobile PAM C60 Water Treatment System [23] a: Top view; b: Side view

Cross-flow microfiltration experiments under constant pressure mode were carried out using a Pall Aria ${ }^{\mathrm{TM}}$ Mobile C60 (PAM C60) (Figure 1) water treatment unit. It's a high-volume and automated microfiltration membrane system in a $12.2 \mathrm{~m}(40 \mathrm{ft})$ high cube container. The PAM C60 can produce up to $7000 \mathrm{~m}^{3}$ of water per day, filtered to $0.1 \mu \mathrm{m}$ for industrial reuse. It contains 60 microfiltration membrane modules ranged into two independent racks. The modules are equipped with Microza (trademark of Asahi Kasei Corporation) polyvinylidene fluoride (PVDF) hollow fiber membranes. Each module provides high active surface area of up to $538 \mathrm{ft}^{2}$. The operating trans-membrane pressure is about 3 bars. In order to avoid membranes fouling, which would shorten the membranes lifetime dramatically, a filter with $300 \mu \mathrm{m}$ pore size was used as a pre-treatment for the cross-flow microfiltration process.

\section{Cleaning procedure}

Membrane fouling causes a decrease in filtration productivity resulting in a decrease in flux with time under constant trans- 
membrane operation [19]. To restore membrane performance two cleaning methods were used: air/water flush and chemical cleaning.

The so-called air/water flush is a forward flush during which air is injected in the supplier pipe. Because air is used, a much more turbulent cleaning system is created. Using air flush means flushing the inside of membranes with an air/ water mixture. The forward flush intervals are from 45 to 60 minutes, and durations are from 40 seconds to 1 minute, depending on the water quality.

During a chemical cleaning process, membranes are soaked with a solution of sodium hypochlorite, citric acid or sodium hydroxide. The solution soaks into the membranes for a number of minutes and after that a forward flush or backward flush is applied. The chemical cleaning step is applied after each 12 hours operation for 60 minutes duration.

\section{Results and Discussion}

\section{Physico-chemical performances}

Table 2: Physico-chemical characteristics of secondary wastewater effluent and permeate.

\begin{tabular}{|c|c|c|c|c|c|c|c|c|c|c|}
\hline \multirow{2}{*}{ Parameter } & \multicolumn{5}{|c|}{ Secondary Effluent } & \multicolumn{5}{|c|}{ Permeate } \\
\hline & Min. & Max. & Mean & St.dv. & NS & Min. & Max. & Mean & St.dv. & NS \\
\hline $\mathrm{pH}$ & 6.74 & 7.35 & 6.97 & 0.19 & 18 & 7.11 & 7.3 & 7.2 & 0.06 & 18 \\
\hline Electric conductivity $(\mathrm{mS} / \mathrm{cm})$ & 2.63 & 3.8 & 3.32 & 0.34 & 18 & 2.6 & 3.76 & 3.31 & 0.32 & 18 \\
\hline Temperature $\left({ }^{\circ} \mathrm{C}\right)$ & 15.1 & 25 & 20.5 & 4.5 & 18 & 15.1 & 25 & 20.5 & 4.5 & 18 \\
\hline Turbidity (NTU) & 117 & 354 & 178.22 & 74.65 & 18 & 0.63 & 62.3 & 12.57 & 20.09 & 18 \\
\hline $\mathrm{SS}(\mathrm{mg} / \mathrm{L})$ & 150 & 400 & 100.55 & 70.71 & 18 & 0 & 0 & 0 & 0 & 18 \\
\hline $\operatorname{COD~}\left(\mathrm{mg} \mathrm{O}_{2} / \mathrm{L}\right)$ & 18.15 & 931.57 & 383.94 & 297.27 & 18 & 7.1 & 142.1 & 71.78 & 48.82 & 18 \\
\hline $\mathrm{BOD}_{5}\left(\mathrm{mg} \mathrm{O}_{2} / \mathrm{L}\right)$ & 81.2 & 406.7 & 261.45 & 135.13 & 8 & 11.9 & 58 & 34.67 & 20.75 & 8 \\
\hline $\mathrm{NH}_{4 .} \mathrm{N}(\mathrm{mg} / \mathrm{L})$ & 33.6 & 229.8 & 173.15 & 96.48 & 18 & 3.64 & 142.1 & 154.71 & 88.62 & 18 \\
\hline
\end{tabular}

St.dv.: Standard deviation; NS: Number of samples.

Results obtained from statistical analyses of the applied secondary wastewater effluent and permeate produced by the cross-flow microfiltration unit are summarized in Table 2. The maximum, minimum, and mean values as well as the standard deviation are presented. Analyses showed that the secondary effluent characteristics varied within a wider range and exhibited relatively higher variability than the treated water for the parameters tested. Variability in the secondary effluent quality may be taken as an indication of an inherent in- plant treatment problem or a problem caused by diurnal variations in influent wastewater flow and characteristics as well as process control practices.

The physico-chemical characteristics of the secondary wastewater effluent and filtered water are depicted in Figure 2. Analyses showed an increase of $\mathrm{pH}$ values in the filtered water (Figure 2(a)). This increase could be explained by the abatement of organic acids present in the applied wastewater effluent.

\section{Analytical methods}

The secondary effluent and permeate were analyzed for suspended solids (SS), chemical oxygen demand (COD), 5- day biochemical demand $\left(\mathrm{BOD}_{5}\right)$, ammonium nitrogen $\left(\mathrm{NH}_{4}-\mathrm{N}\right)$, total coliforms (TC), faecal coliforms (FC) and faecal streptococci (FS). Temperature, $\mathrm{pH}$, electric conductivity and turbidity were measured. All parameters were measured according to the AFNOR standard.

The retention (R) of the MF membrane was calculated using the following equation:

$$
R(\%)=\frac{1-C p}{C f} \times 100
$$

Where $\mathrm{Cf}$ and $\mathrm{Cp}$ are respectively the feed and the permeate concentrations. 
high. In fact, nitrogen poses a major environmental problem due to its high contribution to eutrophication of freshwater bodies. Eutrophication is a condition of an aquatic ecosystem where high nutrient concentrations, such as nitrogen and phosphorus, stimulate algal blooms, degrading the water quality in these aquatic ecosystems [22]. Therefore, controlling phosphorus and nitrogen discharged from municipal and industrial wastewater treatment plants is a key factor in preventing eutrophication of surface waters. In addition to its contribution to eutrophication phenomenon, ammonium nitrogen in wastewater can reduce the effectiveness of chemical cleaning by converting hypochlorite into less active chloramine's species.
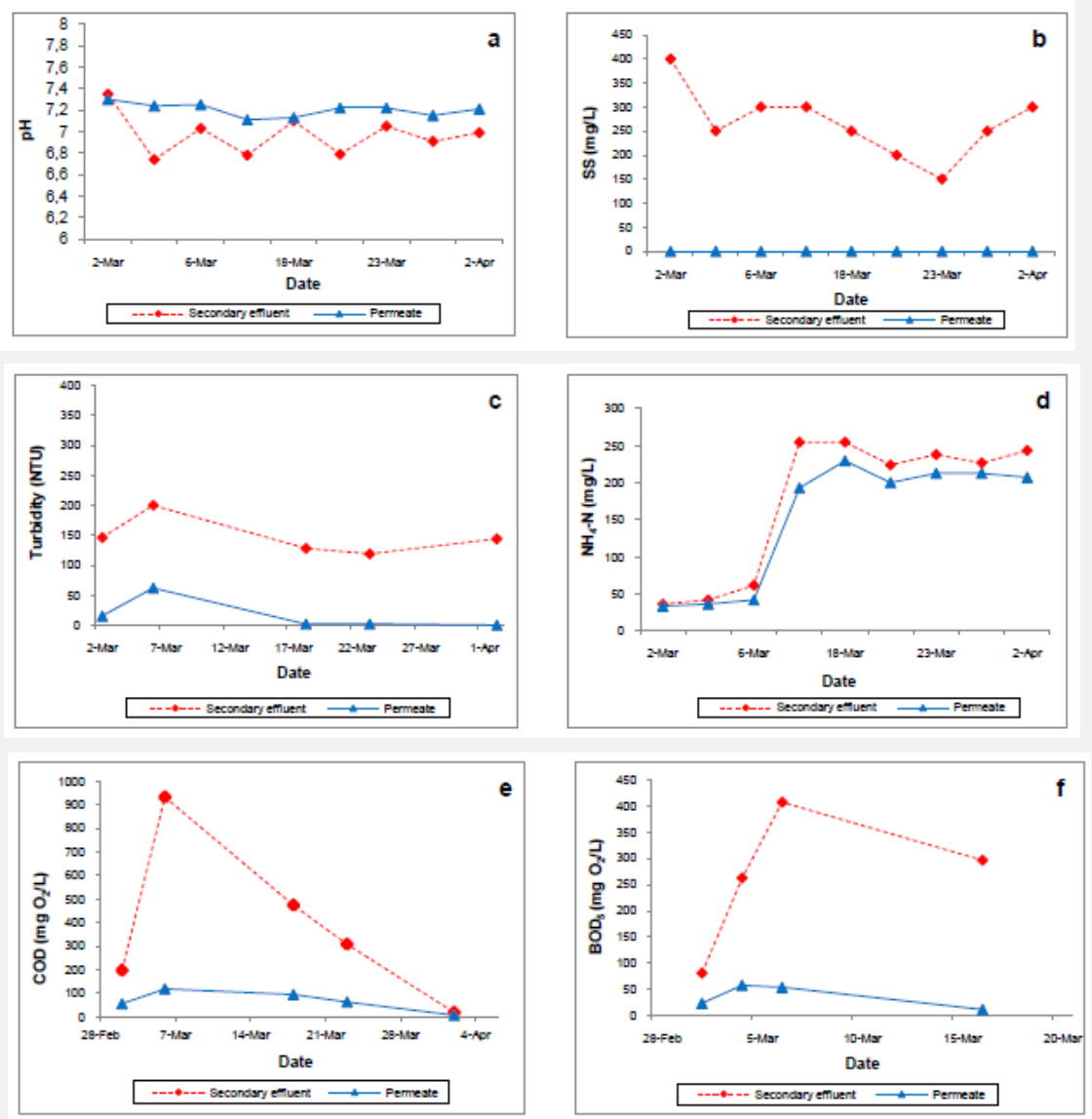

Figure 2: Physico-chemical characteristics of the secondary effluent and permeate

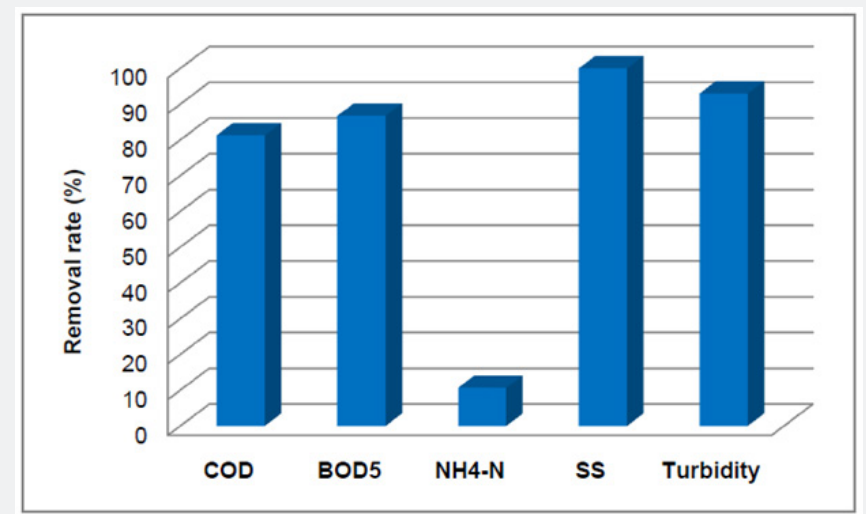

Figure 3: Average removal rates of physico-chemical parameters 
Throughout the experimental period, high rates of organic matter were recorded in the wastewater effluent. The average concentrations of COD and $\mathrm{BOD}_{5}$ were about 383.9 and $261.4 \mathrm{mg}$ $\mathrm{O}_{2} / \mathrm{L}$, respectively. These high concentrations can be explained by a hydraulic or organic overload. There were probably not enough microorganisms or enough time in the aeration basin to adequately treat the organic matter.

In the treated water, the average contents were 71.78 and
$34.67 \mathrm{mg} \mathrm{O}_{2} / \mathrm{L}$, respectively (Table 2 ). The removal rates reached 81.3 and $86.7 \%$, respectively (Figure 3 ). These results confirm the good efficiency of this treatment technique in retaining organic impurities. The high load of suspended solids in the wastewater could cause a rapid flux decline due to the membrane fouling. Despite the fact that ammonia was not adequately removed, the treated water can be used for washing phosphates in the Tunisian company of phosphoric acid.

\section{Bacteriological performances}

Table 3: Bacteriological characteristics of secondary wastewater effluent and permeate.

\begin{tabular}{|c|c|c|c|c|c|c|c|c|c|}
\hline \multirow{2}{*}{ Parameter } & \multicolumn{4}{|c|}{ Secondary Effluent } & \multicolumn{4}{c|}{ Permeate } & \multirow{2}{*}{ Removal Rate log (UFC/100mL) } \\
\cline { 2 - 10 } & Min. & Max. & Mean & NS & Min. & Max. & Mean & NS & 5.62 \\
\hline TC $\log (\mathrm{UFC} / 100 \mathrm{~mL})$ & 0 & 7.36 & 5.62 & 10 & 0 & 0 & 0 & 10 & 2.78 \\
\hline FC $\log (\mathrm{UFC} / 100 \mathrm{~mL})$ & 0 & 6.59 & 2.78 & 10 & 0 & 0 & 0 & 10 & 0.92 \\
\hline FS $\log (\mathrm{UFC} / 100 \mathrm{~mL})$ & 0 & 4.6 & 0.92 & 10 & 0 & 0 & 0 & 10 & \\
\hline
\end{tabular}

The removal efficiency of the technique of cross-flow microfiltration regarding the total coliforms (TC), faecal coliforms (FC), and faecal streptococci (FS) was investigated. Microorganism contents in the secondary wastewater effluent and permeate were measured. Bacteriological characteristics of the applied wastewater effluent and treated water are presented in Table 3. Average contents of pathogenic microorganisms in the secondary effluent were 5.62, 2.78 and $0.92 \log$ unit for total coliforms, faecal coliforms, and faecal streptococci, respectively. Results demonstrated the good disinfection performances of the cross-flow MF technique. All pathogenic bacteria indicators (TC, FC and FS) were efficiently removed from the applied wastewater. Therefore, the PVDF membrane represents a total barrier for this group of bacteria. These results can be explained by the size of microbial cells which is bigger than the pore size of the membrane. Similar results were presented by Sorlini et al. [21], who demonstrated that CFMF using hollow fiber membranes is able to achieve removal rates higher than $98 \%$ for a large number of species of bacteria. The bacteriological quality of permeate was good enough to allow industrial reuse.

\section{Conclusion}

Cross-flow microfiltration seems to be an efficient technique to polish urban wastewater effluents. Results confirmed that this process is performed as an advanced treatment system for the suspended solids and organic matter. However, it is less efficient concerning the reduction of ammonium nitrogen. Data obtained during this study are evidences of the high disinfection capacity of microfiltration membranes. Therefore, the MF process is considered as an interesting issue for the treatment of urban wastewater effluent and it can be an attractive alternative for reusing a significant part of all incoming fresh water.
This process can be used as a tertiary treatment with the aim of removing contaminants from the effluents of conventional wastewater treatment plants. Reuse of tertiary-treated effluent is an economically viable and environmentally sound option for water resource development in the state of Tunisia.

\section{Acknowledgement}

The authors would like to thank the Tunisian Company of Phosphoric Acid for the technical support and the collaboration.

\section{References}

1. Abdessemed D, Nezzal G, Ben Aïm R (1999) Treatment of wastewater by ultrafiltration. Desalination 126: 1-5.

2. Mohammadi T, Esmaeelifar A (2004) Wastewater treatment using ultrafiltration at a vegetable oil factory. Desalination 166: 329-337.

3. Sonune A, Ghate R (2004) Developments in wastewater treatment methods. Desalination 167: 55-63.

4. Gómez M, Plaza F, Garralón G, Pérez J, Gómez MA (2007) A comparative study of tertiary wastewater treatment by physico-chemical-UV process and macrofiltration-ultrafiltration technologies. Desalination 202: $369-376$

5. Jhaveri JH, Murthy ZVP (2016) A comprehensive review on anti-fouling nanocomposite membranes for pressure driven membrane separation processes. Desalination 379: 137-154.

6. Fersi C, Gzara L, Dhabi M (2005) Treatment of textile effluents by membrane technologies. Desalination 185: 399-409.

7. Environmental Protection Agency, U.S. Agency for International Development (1992) Guidelines for water reuse. EPA/625/R-92/004, September, Washington, D.C.

8. Marcucci M, Nosenzo G, Capannelli G, Ciabatti I, Corrieri D, et al. (2001) Treatment and reuse of textile effluents based on new ultrafiltration and other membrane technologies. Desalination 138: 75-82.

9. Tang C, Chen V (2002) Nanofiltration of textile wastewater for reuse. Desalination 143: 11-20. 
10. Fersi C, Dhahbi M (2008) Treatment of textile plant effluent by ultrafiltration and/or nanofiltration for water reuse. Desalination 222: 263-271.

11. Zhu H, Wen X, Huang X (2012) Characterization of membrane fouling in a microfiltration ceramic membrane system treating secondary effluent. Desalination 284: 324-331.

12. Ghandehari S, Montazer-Rahmati MM, Asghari M (2011) A comparison between semi-theoretical and empirical modeling of cross-flow microfiltration using ANN. Desalination 277: 348-355.

13. Rezaei H, Ashtiani FZ, Fouladitajar A (2011) Effects of operating parameters on fouling mechanism and membrane flux in cross-flow microfiltration of whey. Desalination 274: 262-271.

14. Van der Bruggen B, Cornelis G, Vandecasteele C, Devreese I (2005) Fouling of nanofiltration and ultrafiltration membranes applied for wastewater regeneration in the textile industry. Desalination 175 : 111-119.

15. Tchobanoglous Garby J, Bourgeous K, McArdle J, Genest P, Tylla M (1998) Ultrafiltration as an advanced tertiary treatment process for municipal wastewater. Desalination 119: 315-322.

16. Kim YJ, Yun T, Lee S, Kim D, Kim J (2014) Accelerated testing for fouling of microfiltration membranes using model foulants. Desalination 343: 113-119.
17. Wang Z, Cui Y, Wu W, Ji S, Yao J, et al. (2009) The convective model of flux prediction in a hollow-fiber module for a steady-state cross-flow microfiltration system. Desalination 238: 192-209.

18. Diagne F, Malaisamy R, Boddie V, Holbrook RD, Eribo B, et al. (2012) Polyelectrolyte and Silver Nanoparticle Modification of Microfiltration Membranes to Mitigate Organic and Bacterial Fouling. Environ Sci Technol 46(7): 4025-4033.

19. Hajipour M, Soltanieh M, Yazdanshenas M (2010) Investigation of membrane fouling in cross-flow microfiltration of non alcoholic beer and modeling of tubular membrane flow. Desalination 251: 20-28.

20. Vera L, Villarroel-López R, Delgado S, Elmaleh S (1997) Cross-flow microfiltration of biologically treated wastewater. Desalination 114 : 65-75.

21. Sorlini S, Gialdini F, Collivignarelli C (2013) Removal of cyanobacterial cells and Microcystin-LR from drinking water using a hollow fiber microfiltration pilot plant. Desalination 309: 106-112.

22. Ritter WF, Shirmohammadi S (2001) Agricultural Non-point Source Pollution: Watershed Management and Hydrology. Lewis Publishers: Florida, USA.

23. Pall Corporation (2013) Application bulletin. Pall Aria ${ }^{\mathrm{TM}}$ Mobile PAM C60 Water Treatment Systems.

Your next submission with Juniper Publishers will reach you the below assets

- Quality Editorial service

- Swift Peer Review

- Reprints availability

- E-prints Service

- Manuscript Podcast for convenient understanding

- Global attainment for your research

- Manuscript accessibility in different formats

( Pdf, E-pub, Full Text, Audio)

- Unceasing customer service

Track the below URL for one-step submission https://juniperpublishers.com/online-submission.php 